\title{
Species composition and seasonal abundance of sandflies (Diptera: Psychodidae: Phlebotominae) in coffee agroecosystems
}

\author{
Jeanneth Pérez ${ }^{1 /+}$, Armando Virgen 1 , Julio Cesar Rojas ${ }^{1}$, Eduardo Alfonso Rebollar-Téllez², \\ Alfredo Castillo', Francisco Infante', Oscar Mikery¹, Carlos Felix Marina ${ }^{3}$, Sergio Ibáñez-Bernal ${ }^{4}$ \\ 'El Colegio de la Frontera Sur, Tapachula, Chiapas, México ²Facultad de Ciencias Biológicas, Universidad Autónoma de Nuevo León, \\ Nuevo León, México ${ }^{3}$ Instituto Nacional de Salud Pública, Centro Regional de Investigación en Salud Pública, \\ Tapachula, Chiapas, México ${ }^{4}$ Instituto de Ecologia AC, Xalapa, Veracruz, México
}

The composition and seasonal occurrence of sandflies were investigated in coffee agroecosystems in the Soconusco region of Chiapas, Mexico. Insect sampling was performed on three plantations located at different altitudes: Finca Guadalupe Zajú [1,000 m above sea level (a.s.l.)], Finca Argovia (613 m a.s.l.) and Teotihuacán del Valle (429 m a.s.l.). Sandflies were sampled monthly from August 2007-July 2008 using three sampling methods: Shannon traps, CDC miniature light traps and Disney traps. Sampling was conducted for $3 \mathrm{~h}$ during three consecutive nights, beginning at sunset. A total of 4,387 sandflies were collected during the course of the study: 2,718 individuals in Finca Guadalupe Zajú, 605 in Finca Argovia and 1,064 in Teotihuacán del Valle. The Shannon traps captured $94.3 \%$ of the total sandflies, while the CDC light traps and Disney traps captured $4.9 \%$ and $0.8 \%$, respectively. More females than males were collected at all sites. While the number of sandflies captured was positively correlated with temperature and relative humidity, a negative correlation was observed between sandfly numbers and rainfall. Five species of sandflies were captured: Lutzomyia cruciata, Lutzomyia texana, Lutzomyia ovallesi, Lutzomyia cratifer/ undulata and Brumptomyia $s p$. Lu. cruciata, constituting $98.8 \%$ of the total, was the most abundant species. None of the captured sandflies was infected with Leishmania spp.

Key words: Phlebotominae - Lutzomyia - Brumptomyia - coffee agroecosystem - leishmaniases

The leishmaniases are a group of infectious diseases caused by parasites belonging to the genus Leishmania Ross and transmitted by various species of sandflies (Diptera: Psychodidae: Phlebotominae). Of the approximately 800 known Phlebotominae sandfly species, 98 belong to two genera, Phlebotomus and Lutzomyia, which are native to the Old World and New World, respectively, and have been implicated in the transmission of 40 different species of Leishmania (Maroli et al. 2013). The leishmaniases are considered re-emergent diseases by the World Health Organization (WHO) and are endemic in 98 countries. The worldwide incidence of the diseases is approximately two million new cases per year, with an annual mortality of approximately 50,000 individuals and more than 350 million people are at risk of contracting the diseases (WHO 2010). Typically, the leishmaniases occur in four main forms: localised cutaneous leishmaniasis, diffuse cutaneous leishmaniasis, mucocutaneous leishmaniasis and visceral leishmaniasis. The occurrence of leishmaniasis results from the distribution of its vectors and reservoirs; factors such as

doi: 10.1590/0074-0276130224

Financial support: CONACYT, FOMIX-Chiapas (CHIS-2007-C07-

77409), CRISP-CONACYT-FOSSIS-69530, INECOL (10816) (to SIB)

+ Corresponding author: ejperez@ecosur.mx

Received 25 April 2013

Accepted 9 September 2013 deforestation, migration and urbanisation modify habitats and lead to vectors and reservoirs moving beyond their natural geographical ranges (Desjeux 1996, Gratz 1999, Rotureau 2006a).

The relationship between leishmaniasis and agricultural activity has been frequently documented. For example, the relationship between coffee cultivation and the transmission of Leishmania by sandflies has been recorded in Venezuela (Scorza et al. 1985) and Colombia (Alexander 1987, Montoya-Lerma 1990, Alexander et al. 2001) and subsequently in Brazil (Alexander et al. 2002). In Mexico, Sanchez-Tejeda et al. (2001) found that people who spent more time on coffee plantations had a higher risk of contracting the disease. This observation could be explained by the suitability of shade-grown coffee plantations for the resting and breeding of sandflies (Alexander \& Usma 1994). Moreover, this type of agroecosystem presents high biodiversity (Ibarra-Núñez 1990, Perfecto et al. 1996) and promotes the presence of many vertebrates, which in turn act as reservoirs of Leishmania and potential feeding sources for sandflies.

In Mexico, leishmaniasis was first recorded in the Yucatan Peninsula (Seidelin 1912) and to date, leishmaniasis has been reported in 22 of the 32 Mexican states (Sanchez-Tejeda et al. 2001). Chiapas is among the states with the highest prevalence of cutaneous leishmaniasis, with 1,310 cases reported between 1990-2005 (Becker et al. 2005). This state is also one of the two foci of visceral leishmaniasis in Mexico, with 78 cases reported between 1952-2005, of which 33 were reported between 2000-2005 (Becker et al. 2005). The municipalities with the highest prevalence of leishmaniasis in Chiapas are 
Tuxtla Gutiérrez, Chiapa de Corzo, Palenque, Pichucalco, Las Margaritas and Ocosingo (Ibáñez-Bernal et al. 2004, Becker et al. 2005).

The state of Chiapas ranks first in Mexican coffee production, with a total area of 258,835 ha dedicated to the crop (Information Service Agroalimentary and Fishing, Mexico) (siap.gob.mx). In the Soconusco region, located in the southernmost part of the state near the border with Guatemala, coffee is the main agricultural product, representing 37\% of the total cultivated area (Santacruz de León \& Villalba 2009). As in other coffee growing areas of Latin America, the leishmaniases have been reported in a number of localities of the Soconusco region (Ortega-Grillasca \& Vidal-Antonio 1990). Although some preliminary reports of sandfly species inhabiting this region have been published (Ibáñez-Bernal 1999, MikeryPacheco et al. 2012), many aspects of the diseases and their vectors remain unknown. The present study aims to identify the species composition of sandflies, their seasonal abundance and the fluctuation of their populations in coffee agroecosystems. Additionally, the infection of sandflies by Leishmania spp was investigated.

\section{MATERIALS AND METHODS}

Description of the study area - Sampling was conducted at three coffee plantations located in the Soconusco region: Finca Guadalupe Zajú [N159'19.3" W92 ${ }^{\circ} 7^{\prime} 3.7^{\prime \prime}, 1,000 \mathrm{~m}$ above sea level (a.s.1.)], Finca Argovia (N15 07'31.6" W92 ${ }^{\circ} 17^{\prime} 42.8^{\prime \prime}, 613 \mathrm{~m}$ a.s.l.) and

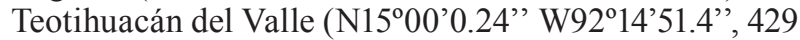
$\mathrm{m}$ a.s.l.). The distance between the coffee plantations is approximately $5 \mathrm{~km}$, which is greater than the approximately $0.5 \mathrm{~km}$ typical dispersion range of sandflies (Alexander 1987). The coffee plantations are situated within an evergreen mountain forest ecosystem at altitudes between 500-1,500 $\mathrm{m}$ and experience a wide range of rainfall amounts. This type of agroecosystem is characterised by a humid environment that promotes abundant vegetation. Typically, heavy rains occur during seveneight months of the year (from late April-November), with an average rainfall of 2,000-3,500 $\mathrm{mm}$ per year. The average annual temperature is $26^{\circ} \mathrm{C}$, with April and May being the hottest months.

Arabic coffee (Coffea arabica L.) was the predominant species at the study sites and was grown under a shade canopy. Coffee agroecosystems have been noted for their great diversity of natural and cultivated vegetation, which includes timber trees, fruit trees, ornamental plants and vegetables (Escamilla-Prado \& DíazCárdenas 2002). Trees such as Terminalia amazonica (Gmel.) Exell and Inga spp were predominant at Finca Guadalupe Zajú and Finca Argovia, while fruit trees, such as rambutan (Nephelium lappaceum L.) and avocado (Persea americana Mill), were the dominant species at Teotihuacán del Valle. In addition, several species of mammals can be found in the coffee plantations of the region: the New World opossums (Marmosa mexicana Merriam, Philander opossum L. and Didelphis virginiana Kerr), the nine-banded armadillo (Dasypus novemcinctus L.) and different species of rodents, such as the Mexican grey squirrel (Sciurus aureogaster Cuvier) and the southern pygmy mouse [Baiomys musculus (Merriam)] (Peters-Grether \& Rodríguez-Camacho 2006). A number of these mammals have been reported as food sources for sandflies in different parts of the world (Young \& Arias 1992, Rotureau 2006b).

Sampling methods - Sandflies were sampled on three consecutive nights at each study site every month from August 2007-July 2008. Sampling was conducted during the $3 \mathrm{~h}$ after sunset, when sandflies are most active (Biagi et al. 1966, Rebollar-Téllez et al. 1996b, Guernaoui et al. 2006). Three capture methods were used: Shannon traps, CDC miniature light traps and Disney traps.

The Shannon trap consisted of a rectangular compartment made from a white sheet measuring $2.5 \times 1.65$ $\mathrm{x} 1.5 \mathrm{~m}$. The trap was placed $50 \mathrm{~cm}$ above the ground and supported by cords hung from the coffee tree branches. Inside the trap, two people served to attract the sandflies. Each person was protected by a long-sleeved shirt, slacks and a fine mesh mosquito net covering the head. All sandflies that entered the trap were collected using mouth aspirators and flashlights.

The CDC miniature light trap, consisting of six VCD with an air gate (BioQuip, Rancho Dominguez, CA, USA), was also hung from a coffee branch using cords with its opening approximately $50 \mathrm{~cm}$ from the ground. The collected material was maintained under refrigeration for the remainder of the night of collection and the sandfly specimens were separated and preserved in $70 \%$ ethanol on the following day.

The Disney trap (Disney 1966) consisted of a metal tray $(50 \times 50 \mathrm{~cm})$ impregnated with castor oil. Each trap was baited with a laboratory mouse inside a screenmetal cage $(15 \times 7 \times 5 \mathrm{~cm})$ placed on the metal tray. To protect the mice and the collected insects from rain, an additional tray was placed above the trap. The operating principle of this trap is based on the fact that sandflies do not land directly on a host; instead, the sandflies often execute short hops around the host. In the Disney trap, this behaviour causes the sandflies to stick to the oiled surfaces around the animal cage. The Disney trap was hung from a coffee tree branch $50 \mathrm{~cm}$ above the ground. After $3 \mathrm{~h}$ of sampling, the traps were removed and examined the following morning and the sandflies were separated. The captured flies were carefully removed with a dissecting needle, washed with a neutral detergent solution (Extran 10\%) and preserved in 70\% ethanol.

Nine traps (1 Shannon, 4 CDC light and 4 Disney) were used on each sampling night. The traps were distributed over 1 ha of the coffee plantation and arranged in a transect with at least $20 \mathrm{~m}$ of distance between each trap. Because of the limited availability of the traps and experimenters, sampling was not performed simultaneously at the three sites. To reduce the bias due to the moon phase (Souza et al. 2005), the sampling dates were alternated among the sites each month. The locations of the CDC light and Disney traps were alternated each night, while the Shannon trap was not moved. The temperature and relative humidity (RH) were recorded at each hour during the sampling period. The rainfall data of Finca Argovia and Finca Guadalupe Zajú were obtained from 
their respective meteorological stations, while the data from Teotihuacán del Valle were obtained from a meteorological station located $1 \mathrm{~km}$ from the sampling site.

Identification of sandflies - The sandflies were prepared and mounted on slides using Euparal medium, following the procedures outlined by Ibáñez-Bernal (2001). The taxonomic keys of Ibáñez-Bernal (1999, 2001, 2002, 2003) and the descriptions of Young and Duncan (1994) were used for species determination. Voucher specimens were deposited at the entomological collections of $\mathrm{El}$ Colegio de la Frontera Sur (ECO-TAP-E-0001L - ECOTAP-E-0006L). We adopted the classification system proposed by Young and Duncan (1994); however, when a taxon is first mentioned in the results, its name is given in parentheses under the phylogenetic classification proposed by Galati (2003).

Infection by Leishmania spp - Twenty percent of the total female sandflies captured were selected at random from different months, traps and sites to determine the level of infection with Leishmania spp. These individuals were deposited in vials containing $80 \%$ ethanol and maintained at $-20^{\circ} \mathrm{C}$ until analysis. The genomic DNA was obtained using previously described methods (Edwards et al. 1991, Pech-May et al. 2010). Polymerase chain reaction (PCR) analysis was used to detect the presence of the parasites. To identify the Leishmania genus, we used conserved sequences of gp63. The success of the DNA extraction was analysed using a conserved sequence of the 18S rRNA gene as a positive control (Kato et al. 2005).

Statistical analysis - The abundance of sandflies at each study site was compared using a $\chi^{2}$ test. The monthly biting rate was obtained from the captures per night in the Shannon traps based on the total number of Lutzomya cruciata females caught and the number of col- lectors inside the trap (Pech-May et al. 2010). The count data of sandfly captures from each site were correlated with climate factors (temperature, $\mathrm{RH}$ and rainfall) using a generalised linear model based on a Poisson distribution (Crawley 1993). The Poisson distribution was chosen because of its appropriateness for studies dealing with insect counts and to control for overdispersion. We assumed that the detection of the sandflies was independent and that individuals were equally detectable across the three sampling sites (Fowler et al. 1998). The statistical tests were performed using $\mathrm{R}$ version 2.11.1 ( $\mathrm{R}$ Development Core Team 2013). A value of $p<0.05$ was considered significant for all tests.

\section{RESULTS}

A total of 4,387 sandflies were collected during the course of the study period from the three study sites: 2,718 individuals in Finca Guadalupe Zajú, 605 in Finca Argovia and 1,064 in Teotihuacán del Valle. The Shannon traps, CDC light traps and Disney traps captured $94.3 \%, 4.9 \%$ and $0.8 \%$ of the sandfly individuals, respectively (Table I).

Five species of Phlebotominae sandflies were captured: Lutzomyia cruciata (Coquillett) $[=$ Lu. (Tricholateralis) cruciata (Coquillett)]; Lutzomyia texana (Dampf) [= Psathyromyia (Forattiniella) texana (Dampf)]; Lutzomyia ovallesi (Ortiz) [= Pintomyia (Pifanomyia) ovallesi (Ortiz)]; Lutzomyia cratifer/undulata (Fairchild and Hertig) [= Psathyromyia (Psathyromyia) cratifer or undulata (Fairchild and Hertig)] and Brumptomyia sp. Lu. cruciata represented $98.9 \%$ of the total number of captured individuals. A higher proportion of females $(99.2 \%)$ than males $(0.8 \%)$ was captured at all sites. The greatest proportion of the males $(91 \%)$ was captured with the CDC light traps. The greatest number of males was caught in Finca Guadalupe Zajú: a total of 29 individuals belonging to four different species of sandfly.

\section{TABLE I}

Sandflies captured during sampling over a one-year period in three coffee plantations located at different altitudes

\begin{tabular}{|c|c|c|c|c|c|c|c|}
\hline \multirow[b]{2}{*}{ Site and species } & \multicolumn{2}{|c|}{ Shannon } & \multicolumn{2}{|c|}{$\mathrm{CDC}$} & \multicolumn{2}{|c|}{ Disney } & \multirow[b]{2}{*}{ Total } \\
\hline & 우 & $\hat{\sigma}$ & q & $\widehat{0}$ & 우 & 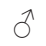 & \\
\hline \multicolumn{8}{|l|}{ Guadalupe Zajú } \\
\hline Lutzomyia cruciata & 2,553 & 2 & 86 & 9 & 27 & 0 & 2,677 \\
\hline Lutzomyia texana & 0 & 0 & 11 & 16 & 0 & 0 & 27 \\
\hline Lutzomyia ovallesi & 10 & 0 & 2 & 1 & 0 & 0 & 13 \\
\hline Brumptomyia sp. & 0 & 1 & 0 & 0 & 0 & 0 & 1 \\
\hline \multicolumn{8}{|l|}{ Argovia } \\
\hline Lu. cruciata & 525 & 0 & 68 & 0 & 5 & 0 & 598 \\
\hline Lu. texana & 1 & 0 & 3 & 3 & 0 & 0 & 7 \\
\hline \multicolumn{8}{|l|}{ Teotihuacán del Valle } \\
\hline Lu. cruciata & 1,045 & 0 & 13 & 2 & 3 & 0 & 1,063 \\
\hline Lutzomyia cratifer/undulata & 1 & 0 & 0 & 0 & 0 & 0 & 1 \\
\hline
\end{tabular}


We found that the abundance of Lu. cruciata, Lu. texana and Lu. ovallesi was favoured by high altitude. Significant differences were observed in the abundance of Lu. cruciata at the three study sites $\left[\chi^{2}=1,661.4\right.$; degrees of freedom $(\mathrm{df})=2 ; \mathrm{p}<0.001]$ and the species was most abundant at Finca Guadalupe Zajú. A clear correlation of Lu. cruciata abundance with altitude was observed for the capture numbers of the CDC and Disney traps; however, this correlation was not observed when the numbers from the Shannon traps were used. The abundance of $L u$. texana was also favoured by high altitude $\left(\chi^{2}=\right.$ $33.5 ; \mathrm{df}=2 ; \mathrm{p}<0.0001)$. This species was more abundant (79.4\% of individuals) at Finca Guadalupe Zajú than at the other sites and it was not found at Teotihuacán del Valle. Finally, $L u$. ovallesi was only detected at Finca Guadalupe Zajú.

Captures of sandflies were influenced by climatic factors (Table II). Sandfly abundance was positively correlated with temperature and RH and negatively correlated with rainfall. The number of captured sandflies was observed to decrease as the temperature decreased. The greatest numbers of sandflies were captured during the first hour of sampling, when the temperature was highest and the lowest numbers were captured during the third hour of sampling, when the temperature was lowest (Fig. 1). We conducted sampling only for the 3 $\mathrm{h}$ after sunset, as sandfly activity decreases drastically after this period (Biagi et al. 1966, Williams 1966, Rebollar-Téllez et al. 1996b, Pech-May et al. 2010). The dynamics of the fluctuations in sandfly populations in relation to rainfall are presented in Fig. 2. The least numerous captures occurred in August, September and October, coinciding with the period of highest rainfall. The month with the greatest sandfly abundance varied across the three sites. January, March and May were the months with the most numerous captures in Finca Argovia, Finca Guadalupe Zajú, Teotihuacán del Valle, respectively and 305, 929 and 299 individuals, respectively, were captured.

Because of the small number of specimens captured for most of the sandfly species, the monthly biting rate

\section{TABLE II}

Statistical analysis results for the influence of climatic factors on the captures of sandflies in three plantations located at different altitudes

\begin{tabular}{lccc}
\hline Source & $\mathrm{F}$ & $\mathrm{df}$ & $\mathrm{p}$ \\
\hline Finca & 73.76 & $2 ; 297$ & $<0.0001$ \\
Temperature & 73.81 & $1 ; 297$ & $<0.0001$ \\
Rainfall & 89.33 & $1 ; 297$ & $<0.0001$ \\
RH & 8.71 & $1 ; 297$ & 0.003 \\
Finca x temperature & 0.17 & $2 ; 291$ & 0.842 \\
Finca x rainfall & 1.80 & $2 ; 291$ & 0.165 \\
Finca x RH & 2.23 & $2 ; 291$ & 0.107 \\
\hline
\end{tabular}

df: degrees of freedom; F: statistic value; RH: relative humidity. was calculated for Lu. cruciata only. Fig. 3 represents the average number of females captured per night. The highest biting rate occurred at Finca Guadalupe Zajú during March, April and May, followed by Teotihuacán del Valle in May and Finca Argovia in January.

Infection by Leishmania spp - None of the 840 females examined were positive for Leishmania spp. All the females examined were Lu. cruciata, with the exception of one specimen of Lu. texana.

\section{DISCUSSION}

The distribution and abundance of vectors are the best indicators of the potential risk of a vector-borne disease. In this regard, the main contribution of our study is that it provides a systematic sampling of the composition of the Phlebotominae species inhabiting the coffee plantations in the Soconusco region. The study also provides information on the distribution of the species along the altitudinal gradient and the fluctuations in their populations over time. Forty-four species of sandflies have been recorded in Mexico to date, 25 of which have been found in Chiapas (Young \& Duncan 1994, Ibáñez-Bernal et al. 2004, Mikery-Pacheco et al. 2012). In this study, we discovered a previously undescribed species belonging to the genus Brumptomyia. As we only collected a single specimen of this species, additional samplings are being taken in the field in an attempt to obtain more specimens, which will enable us to describe this taxon (SIBernal et al., unpublished observations).

We have established that $\mathrm{Lu}$. cruciata is the most dominant species in the coffee agroecosystem, followed by $L u$. texana and $L u$. ovallesi. The most numerous sandfly captures occurred during the first $2 \mathrm{~h}$ after sunset. Rebollar-Téllez et al. (1996b) reported that the peak time for the capture of specimens occurred between 06:00 pm7:00 pm in the state of Campeche, Mexico. The temperature and/or RH at this time of day may be more suitable

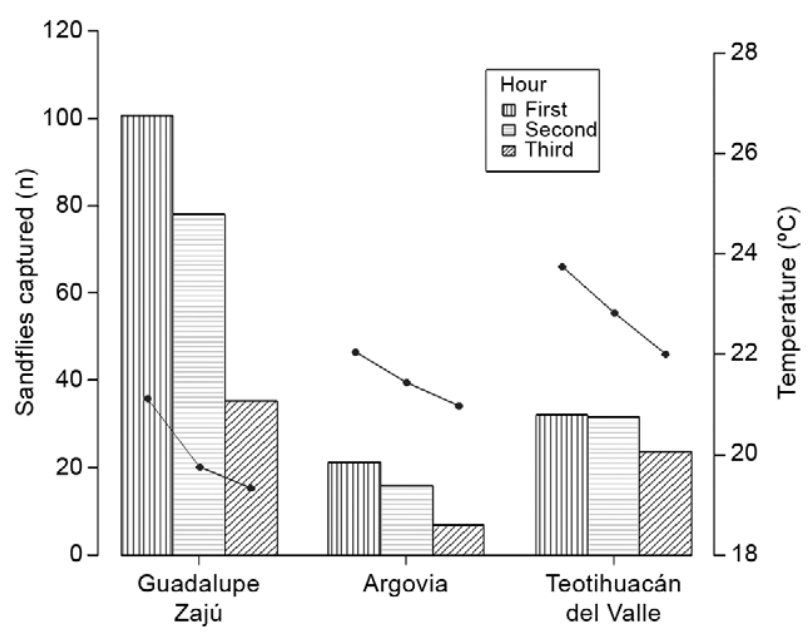

Fig. 1: hourly activity of Lutzomyia cruciata and its relationship with ambient temperature in three coffee plantations located at different altitudes. Bars show the average of sandflies captured and lines show the average temperature. 
for the activity of this species; indeed, our results show that an increase in these two factors results in an increase in the number of sandflies captured. Previous studies have also shown that these climatic factors are crucial to the activity of Phlebotominae (Guernaoui et al. 2006).

Importantly, the diversity of species captured may have been influenced by the sampling method used. Generally, traps that use animal bait capture females while they are seeking blood meals, whereas traps that use light capture females of groups or species that present positive phototropism (Alexander 2000). Anthropophilic species, such as Lu. cruciata (Williams 1965), are well known to be captured in Shannon traps (Pérez et al. 1988). This species has been observed as dominant in a number of different studies that have used traps with human bait (Biagi et al. 1966, Cruz-Ruiz et al. 1994, Rebollar-Téllez et al. 2005, Pech-May et al. 2010, SánchezGarcía et al. 2010). This factor could explain the species abundance observed in the present study.

Despite the nearly 1:1 natural sex ratio of these species (Killick-Kendrick 1999), more females than males were captured during this study. A possible explanation is the fact that trapping with different attractants preferentially samples host-seeking females (Alexander 2000).

$L u$. cruciata is the Phlebotominae species most frequently recorded in captures in Mexico, suggesting a nationwide distribution and this species has been col-
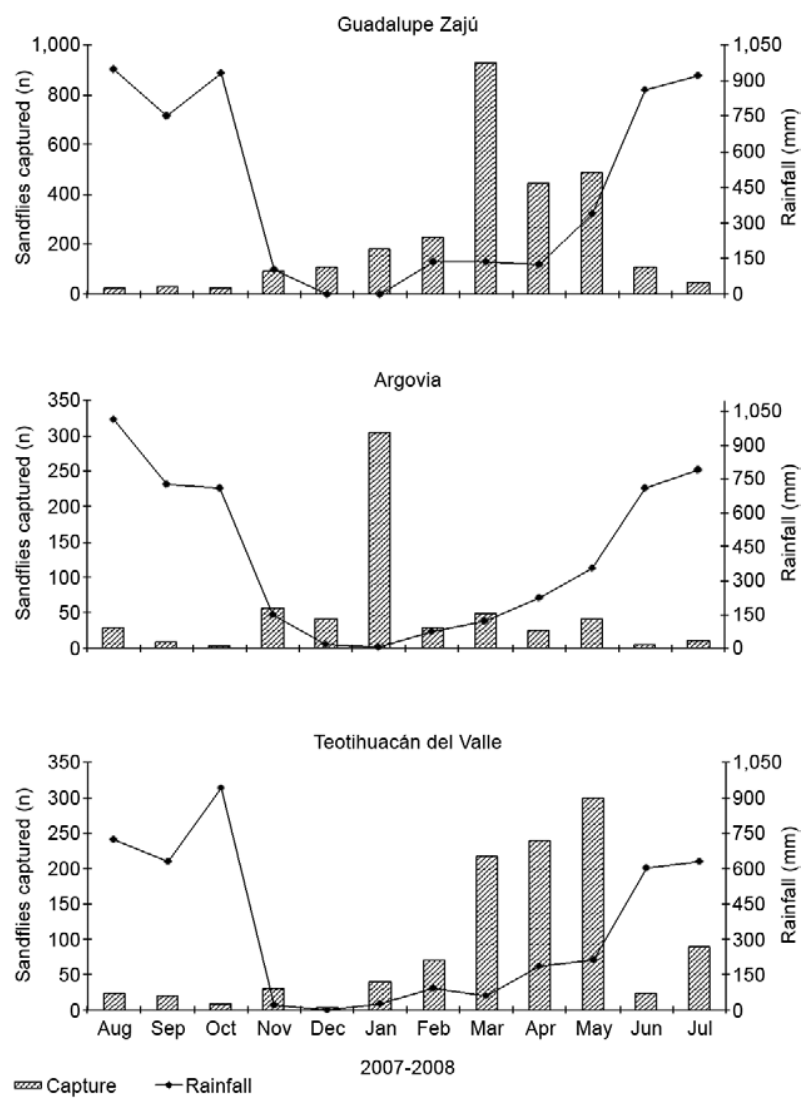

Fig. 2: sandflies captured vs. rainfall during a year of sampling in three coffee plantations located at different altitudes. lected in many foci of leishmaniasis, including endemic zones in the south of the country (Rebollar-Téllez et al. 1996a, 2005). Recently, Lu. cruciata has been found to be infected by Leishmania mexicana (Biagi) in the states of Yucatan, Campeche and Quintana Roo (Canto-Lara et al. 2007, Pech-May et al. 2010, Sánchez-García et al. 2010). Additionally, a recent study conducted in Chiapas found that this species possesses high genetic diversity, suggesting the existence of at least three different lineages (Pech-May et al. 2013).

The geographical distribution of $\mathrm{Lu}$. ovallesi in Mexico covers the states of Campeche, Quintana Roo and Chiapas (Ibáñez-Bernal 1999). This anthropophilic species is a suspected vector of Leishmania braziliensis in Belize, Colombia, Honduras, Mexico, Nicaragua and Panama, as well as a confirmed vector of the species in Guatemala (Rowton et al. 1992) and Venezuela (Feliciangeli et al. 1988, Bonfante-Garrido et al. 1991). $L u$. ovallesi has also been confirmed as a vector of $L$. mexicana in Venezuela (Jorquera et al. 2005).

In Mexico, Lu. texana has been recorded in Chiapas, Guerrero, Jalisco, Morelos, Nayarit, Nuevo León, Oaxaca, San Luis Potosí, Tamaulipas and Veracruz (IbáñezBernal 2002, Ibáñez-Bernal et al. 2011, Mikery-Pacheco et al. 2012, Rodríguez-Rojas 2012). In the present study, the capture of this species was limited to the CDC light traps, with the exception of one female caught with the Shannon trap. This observation is in agreement with the reports of Lu. texana as a non-anthropophilic species. These results are similar to those reported for Campeche and Yucatán (Rebollar-Téllez et al. 2005, 2006).

Lu. cratifer/undulata and Brumptomyia sp. were only represented by single captured individuals; therefore, these species can be considered of low prevalence in the Soconusco region. Regarding Lu. cratifer/undulata, the single specimen collected was a female, taxonomically indistinguishable between the two species; the species have been reported as sympatric in Mesoamerica (Ibáñez-Bernal 2002). Both species have been previously recorded in Chiapas and they are not considered anthropophilic (Ibáñez-Bernal 2002).

Although no Leishmania spp were detected in this study, the risk of these diseases in the region cannot be

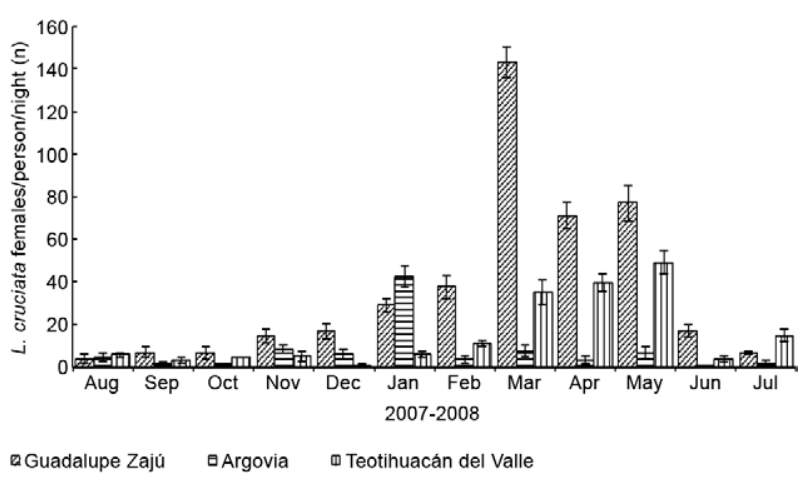

Fig. 3: monthly biting rate of Lutzomyia cruciata (mean \pm standard error) in three coffee plantations located at different altitudes. 
ignored. As mentioned previously, the coffee zone of the Soconusco region is an area of high biodiversity that favours the presence of the vectors and reservoir hosts of Leishmania. Moreover, the high level of human migration from Central America to Mexico contributes to the dispersion of diseases. In fact, human migration is considered the principal factor underlying the urbanisation of the leishmaniases (Desjeux 2002). Most agricultural workers employed in the region, particularly in the coffee plantations during the harvest season, originate from Guatemala (Ángeles-Cruz 2010), where leishmaniases have also been recorded (Herwaldt et al. 1992). Two species of Lutzomyia considered to be suspect or proven vectors of several species of Leishmania are known to be present in the region. Reservoir hosts are also present and the protozoon parasites could eventually be integrated into this complex environment and produce the diseases in humans.

\section{ACKNOWLEDGEMENTS}

To Gustavo Rodas (ECOSUR), José Muñoz and Magne Roblero (CRISP-INSP) and Nohemi Cigarroa, for technical support, to Javier Valle (ECOSUR), for statistical advice, and to Marco Lucas, Bruno Giesemann and Eufronio Díaz, for allowing us to conduct this study on their fincas.

\section{REFERENCES}

Alexander B 1987. Dispersal of Phlebotominae sandflies (Diptera: Psychodidae) in a Colombian coffee plantation. J Med Entomol 24: $552-558$

Alexander B 2000. Sampling methods for phlebotomine sandflies. Med Vet Entomol 14: 109-122.

Alexander B, Agudelo LA, Navarro F, Ruiz F, Molina J, Aguilera G, Quiñonez ML 2001. Phlebotomine sandflies and leishmaniasis risk in Colombian coffee plantations under two systems of cultivation. Med Vet Entomol 15: 364-373.

Alexander B, de Oliveira EB, Haigh E, de Almeida LL 2002. Transmission of Leishmania in coffee plantations of Minas Gerais, Brazil. Mem Inst Oswaldo Cruz 97: 627-630.

Alexander B, Usma MC 1994. Potential source of sugar for the phlebotomine sandfly (Diptera: Psychodidae) in a Colombian coffee plantation. Ann Trop Med Parasitol 88: 543-549.

Ángeles-Cruz H 2010. Las migraciones internacionales en la frontera sur de México. In F Alba, MA Castillo, G Verduzco (eds.), Los grandes problemas de México. III. Migraciones internacionales, El Colegio de México, México DF, p. 437-479.

Becker I, Carrada-Figueroa G, Gudiño-Zayas M, González C, Berzunza-Cruz M, Rivas-Sánchez B, Velasco-Castrejón O 2005. Análisis de la leishmaniasis en México. Proceedings of the Consulta de expertos OPS/OMS sobre la leishmaniasis visceral en las Américas, 2005 Nov 23-25, Brasília, OPS/OMS, p. 23-25.

Biagi F, de Biagi AM, Beltrán F 1966. Actividad horaria de Phlebotomus antropofílicos en la Península de Yucatán. Rev Inv Salud Publica (México) 26: 73-77.

Bonfante-Garrido R, Urdaneta R, Urdaneta I, Alvarado J 1991. Natural infection of Lutzomyia ovallesi (Diptera: Psychodidae) with Leishmania in Duaca, Lara state, Venezuela. Trans $R$ Soc Trop Med Hyg 85: 61.

Canto-Lara SV, Bote-Sánchez MD, Rebollar-Téllez EA, AndradeNarvaez FJ 2007. Detection and identification of Leishmania kDNA in Lutzomyia olmeca olmeca and Lutzomyia cruciata
(Diptera: Psychodidae) by polymerase chain reaction in Southern Mexico. Entomol News 118: 217-222.

Crawley MJ 1993. GLIM for ecologists - Methods in ecology, Blackwell Science, New Jersey, 392 pp.

Cruz-Ruiz AL, García-Rejón J, Manrique-Saide P, Pérez-Mutul J 1994. Taxonomical identification of anthropophilic species of Lutzomyia in Quintana Roo, Peninsula of Yucatán, Mexico. Rev Biomed 5: 127-131.

Desjeux P 1996. Leishmaniasis. Public health aspects and control. Clin Dermatol 14: 417-423.

Desjeux P 2002. Urbanisation of the leishmaniases. In Canine leishmaniasis: moving towards a solution. Proceedings of the 2nd International Canine Leishmaniasis Forum, February 6-9 2002, Sevilla, $102 \mathrm{pp}$.

Disney RH 1966. A trap for phlebotomine sandflies attracted to rats. Bull Entomol Res 56: 445-451.

Edwards K, Johnstone C, Thompson C 1991. A simple and rapid method for the preparation of plant genomic DNA for PCR analysis. Nucleic Acids Res 19: 1349.

Escamilla-Prado E, Díaz-Cárdenas S 2002. Sistemas de cultivo de café en México, Universidad Autónoma Chapingo, México DF, 57 pp.

Feliciangeli MD, Reyes RM, Limongi JE 1988. Natural infection of Lutzomyia ovallesi (Diptera: Psychodidae) with parasites of the Leishmania braziliensis complex in a restricted focus of cutaneous leishmaniases in northern Venezuela. Mem Inst Oswaldo Cruz 83: 393-394.

Fowler J, Cohen L, Harvis P 1998. Practical statistics for field biology, 2nd ed., John Wiley \& Sons, London, 259 pp.

Galati EAB 2003. Morfologia e taxonomia: classificação de Phlebotominae. In EF Rangel, R Lainson (eds.), Flebotomíneos do Brasil, Fiocruz, Rio de Janeiro, p. 23-51.

Gratz NG 1999. Emerging and resurging vector-borne diseases. Annu Rev Entomol 44: 51-75.

Guernaoui S, Boussaa S, Pesson B, Boumezzough A 2006. Nocturnal activity of phlebotomine sandflies (Diptera: Psychodidae) in a cutaneous leishmaniasis focus in Chichaoua, Morocco. Parasitol Res 98: 184-188.

Herwaldt BL, Arana BA, Navin TR 1992. The natural history of cutaneous leishmaniasis in Guatemala. J Infect Dis 165: 518-527.

Ibáñez-Bernal S 1999. Phlebotominae (Diptera: Psychodidae) de México. I. Brumptomyia Franca y Parrot; Lutzomyia Franca, las especies de L. (Lutzomyia) Franca y del grupo verrucarum. Folia Entomol Mex 107: 61-116.

Ibáñez-Bernal S 2001. Phlebotominae (Diptera: Psychodidae) de México. II. Las especies de Lutzomyia (Coromyia) Barretto, del grupo delpozoi y de Lutzomyia (Dampfomyia) Addis. Folia Entomol Mex 40: 17-46.

Ibáñez-Bernal S 2002. Phlebotominae (Diptera: Psychodidae) de México. III. Las especies de Lutzomyia (Psathyromyia) Barretto, del grupo aragoi, de L. (Trichopygomyia) Barretto, del grupo dreisbachi y de L. (Nyssomyia) Barretto. Folia Entomol Mex 41: 149-183.

Ibáñez-Bernal S 2003. Phlebotominae (Diptera: Psychodidae) de México. IV. Las especies de Lutzomyia (Psychodopygus) Mangabeira, L. (Micropygomyia) Barretto, Lutzomyia grupo oswaldoi, L. (Helcocyrtomyia) Barretto y especies del género sin agrupar. Folia Entomol Mex 42: 109-152.

Ibáñez-Bernal S, Rodríguez-Domínguez G, Gómez-Hernández CH, Ricardez-Esquinca JR 2004. First record of Lutzomyia evansi 
(Nuñez-Tovar 1924) in Mexico (Diptera: Psychodidae, Phlebotominae). Mem Inst Oswaldo Cruz 99: 127-129.

Ibáñez-Bernal S, Suárez-Landa T, Mendoza F 2011. An updated checklist of the Phlebotominae sandflies of Veracruz, Mexico (Diptera: Psychodidae: Phlebotominae). Zootaxa 2928: 29-40.

Ibarra-Núñez G 1990. Los artrópodos asociados a cafetos en un cafetal mixto del Soconusco, Chiapas, México. I. Variedad y abundancia. Folia Entomol Mex 79: 207-231.

Jorquera A, González R, Marchán-Marcano E, Oviedo M, Matos M 2005. Multiplex-PCR for detection of natural Leishmania infection in Lutzomyia spp captured in an endemic region for cutaneous leishmaniasis in state of Sucre, Venezuela. Mem Inst Oswaldo Cruz 100: 45-48.

Kato H, Uezato H, Katakura K, Calvopiña M, Marco JD, Barroso PA, Gomes EA, Mimori T, Korenaga M, Iwata H, Nonaka S, Hashiguchi Y 2005. Detection and identification of Leishmania species within naturally infected sandflies in the Andean areas of Ecuador by polymerase chain reaction. Am J Trop Med Hyg 72: 87-93.

Killick-Kendrick R 1999. The biology and control of phlebotomine sandflies. Clin Dermatol 17: 279-289.

Maroli M, Feliciangeli MD, Bichaud L, Charrel RN, Gradoni L 2013. Phlebotominae sandflies and the spreading of leishmaniases and other diseases of public health concern. Med Vet Entomol 27: 123-147.

Mikery-Pacheco O, Marina-Fernández C, Ibáñez-Bernal S, SánchezGuillén D, Castillo-Vera A 2012. Infección natural de Lutzomyia cruciata (Diptera: Psychodidae, Phlebotominae) con Wolbachia en cafetales de Chiapas, México. Acta Zool Mex 28: 401-413.

Montoya-Lerma J 1990. Transmisión de leishmaniasis tegumentaria en zonas cafeteras de Colombia. Entomólogo 66: 1-2.

Ortega-Grillasca F, Vidal-Antonio E 1990. Prevalencia de leishmaniasis en tres localidades del Soconusco Chiapas (Tuxtla Chico, Tapachula y Escuintla), Tesis de Licenciatura, Universidad Nacional Autónoma de Chiapas, México DF, 83 pp.

Pech-May A, Escobedo-Ortegón FJ, Berzuna-Cruz M, RebollarTéllez EA 2010. Incrimination of four sandfly species previously unrecognized as vectors of Leishmania parasites in Mexico. Med Vet Entomol 24: 150-161.

Pech-May A, Marina CF, Vázquez-Domínguez E, Berzunza-Cruz M, Rebollar-Téllez EA, Narvaez-Zapata JA, Moo-Llanes D, IbáñezBernal S, Ramsey JM, Becker I 2013. Genetic structure and divergence in populations of Lutzomyia cruciata, a phlebotomine sandfly (Diptera: Psychodidae) vector of Leishmania mexicana in southeastern Mexico. Infect Genet Evol 16: 254-262.

Pérez JE, Villaseca P, Llanos-Cuentas A, Campos M, Guerra H 1988. Técnicas para colectar "titiras” (Lutzomyia spp, Diptera: Psychodidae) en ambientes altoandinos peruanos. Rev Per Ent 30: 77-80.

Perfecto I, Rice RA, Greenberg R, van der Voort ME 1996. Shade coffee: a disappearing refuge for biodiversity. BioScience 46: 598-608.

Peters-Grether W, Rodríguez-Camacho A 2006. Biodiversidad en fincas cafetaleras del Soconusco, Chiapas, México. Informe para el Programa Verde Ventures de Conservation International, Washington DC, ECOSUR, 28 pp.

R Development Core Team 2013. R: a language and environment for statistical computing. Available from: R-project.org/.

Rebollar-Téllez EA, Orilla-Moguel H, Dzul-Manzanilla FA, CheMendoza A, Manrique-Saide P, Zapata-Peniche A 2006. An update on the phlebotomine sandfly (Diptera: Phlebotomidae) fauna of Yucatán, Mexico. Entomol News 117: 21-24.
Rebollar-Téllez EA, Ramírez-Fraire A, Andrade-Narvaez FJ 1996a. A two years study on vectors of cutaneous leishmaniasis. Evidence for sylvatic transmission cycle in the state of Campeche, Mexico. Mem Inst Oswaldo Cruz 91: 555-560.

Rebollar-Téllez EA, Reyes-Villanueva F, Fernández-Salas I, AndradeNarvaez FJ 1996b. Population dynamics and biting rhythm of the anthropophilic sandfly Lutzomyia cruciata (Diptera: Psychodidae) in southeast Mexico. Rev Inst Med Trop São Paulo 38: 29-33.

Rebollar-Téllez EA, Tun-Ku E, Manrique-Saide P, Andrade-Narvaez FJ 2005. Relative abundance of sandfly species (Diptera: Phlebotominae) in two villages in the same area of Campeche, in southern Mexico. Ann Trop Med Parasitol 99: 193-201.

Rodríguez-Rojas JJ 2012. Aspectos ecológicos de los vectores de leishmaniasis (Diptera: Psychodidae), de la tripanosomiasis americana (Hemiptera: Reduviidae) y de sus reservorios (Mammalia: Rodentia) en localidades selectas de Nuevo León y Tamaulipas, México, Tesis de Licenciatura, Universidad Autónoma de Nuevo León, Nuevo León, 84 pp.

Rotureau B 2006a. Are new world leishmaniasis becoming anthroponoses? Med Hypotheses 67: 1235-1241.

Rotureau B 2006b. Ecology of the Leishmania species in the Guianan ecoregion complex. Am J Trop Med Hyg 74: 81-96.

Rowton E, de Mata M, Rizzo N, Porter CH, Navin TR 1992. Isolation of Leishmania braziliensis from Lutzomyia ovallesi (Diptera: Psychodidae) in Guatemala. Am J Trop Med Hyg 46: 465-468.

Sánchez-García L, Berzunza-Cruz M, Becker-Fauser I, RebollarTéllez EA 2010. Sandflies naturally infected by Leishmania (L.) mexicana in the peri-urban area of Chetumal city, Quintana Roo, Mexico. Trans R Soc Trop Med Hyg 104: 406-411.

Sanchez-Tejeda G, Rodríguez N, Parra CI, Hernandez-Montes O, Barker DC, Monroy-Ostria A 2001. Cutaneous leishmaniasis caused by members of Leishmania braziliensis complex in Nayarit, state of Mexico. Mem Inst Oswaldo Cruz 96: 15-19.

Santacruz de León EE, Villalba EP 2009. Atraso económico, migración y remesas: el caso del Soconusco, Chiapas, México. Convergencia 50: 57-77.

Scorza JV, Castillo L, Rezzano S, Márquez M, Márquez JC 1985. El papel del cafeto en la endemicidad de la leishmaniasis cutánea en Venezuela. Bol Dir Malariol Saneam Ambient 25: 82-87.

Seidelin H 1912. Leishmaniasis and babesiasis in Yucatán. Ann Trop Med Parasitol 6: 295-299.

Souza NA, Andrade-Coelho CA, Silva VC, Peixoto AA, Rangel EF 2005. Moonlight and blood-feeding behaviour of Lutzomyia intermedia and Lutzomyia whitmani (Diptera: Psychodidae: Phlebotominae), vectors of American cutaneous leishmaniasis in Brazil. Mem Inst Oswaldo Cruz 100: 39-42.

WHO - World Health Organization 2010. Control of the leishmaniases. WHO Tech Rep Ser 949: 1-202.

Williams P 1965. Observations on the phlebotomine sandflies of British Honduras. Ann Trop Med Parasitol 59: 393-404.

Williams P 1966. The biting rhythms of some anthropophilic phlebotomine sandflies in British Honduras. Ann Trop Med Parasitol 60: 357-364.

Young DG, Arias JR 1992. The phlebotomine sandflies in the Americas, Pan American Health Organization, Washington DC, 26 pp.

Young DG, Duncan MA 1994. Guide to the identification and geographic distribution of Lutzomyia sandflies in Mexico, the West Indies, Central and South America (Diptera: Psychodidae). Mem Am Entomol Inst 54: 1-881. 